\title{
Biogenic amine production by the wine Lactobacillus brevis IOEB 9809 in systems that partially mimic the gastrointestinal tract stress
}

\author{
Pasquale Russo ${ }^{1,2}$, Pilar Fernández de Palencia ${ }^{1}$, Andrea Romano ${ }^{3}$, María Fernández ${ }^{4}$, Patrick Lucas ${ }^{3}$, \\ Giuseppe Spano ${ }^{2}$ and Paloma López ${ }^{1 *}$
}

\begin{abstract}
Background: Ingestion of fermented foods containing high levels of biogenic amines (BA) can be deleterious to human health. Less obvious is the threat posed by BA producing organisms contained within the food which, in principle, could form BA after ingestion even if the food product itself does not initially contain high BA levels. In this work we have investigated the production of tyramine and putrescine by Lactobacillus brevis IOEB 9809, of wine origin, under simulated gastrointestinal tract (GIT) conditions.

Results: An in vitro model that simulates the normal physiological conditions in the human digestive tract, as well as Caco-2 epithelial human cell lines, was used to challenge L. brevis IOEB 9809, which produced both tyramine and putrescine under all conditions tested. In the presence of BA precursors and under mild gastric stress, a correlation between enhancement of bacterial survival and a synchronous transcriptional activation of the tyramine and putrescine biosynthetic pathways was detected. High levels of both BA were observed after exposure of the bacterium to Caco-2 cells.

Conclusions: L. brevis IOEB 9809 can produce tyramine and putrescine under simulated human digestive tract conditions. The results indicate that BA production may be a mechanism that increases bacterial survival under gastric stress.
\end{abstract}

Keywords: Biogenic amines, Lactic acid bacteria, Putrescine, Tyramine, Food safety, Food toxicity

\section{Background}

Biogenic amines (BA) are natural toxins that can occur in fermented foods and beverages and may cause adverse health effects [1-3]. BA production in foodstuffs is mainly due to microbial metabolism of amino acids, with lactic acid bacteria (LAB) being the primary agents [4]. Tyramine and putrescine are the BA most frequently encountered [5].

Lactobacillus and Enterococcus spp. are often implicated in tyramine formation resulting from tyrosine decarboxylation [6-8]. Tyramine production has been observed in cheeses, fermented sausages and beverages [reviewed by 2,3$]$ and factors that influence tyramine

\footnotetext{
*Correspondence: plg@cib.csic.es

'Department of Molecular Microbiology and Infection Biology, Centro de Investigaciones Biológicas, C.S.I.C., Ramiro de Maeztu 9, Madrid 28040, Spain Full list of author information is available at the end of the article
}

biosynthesis have been reported [9,10]. A relationship between tyramine content of foods, and illnesses after ingestion, has been established [reviewed by 2]. These illnesses include headache, migraine, neurological disorders, nausea, vomiting, respiratory disorders and hypertension. Moreover, the adherence of some enteropathogens, such as Escherichia coli O157:H7, to intestinal mucosa is increased in the presence of tyramine [11]. Bacteria can produce putrescine from ornithine, using ornithine decarboxylase [12], or, alternatively from agmatine, using agmatine deiminase $[13,14]$. Putrescine synthesis was initially observed mainly in Enterobacteriacea, though recently it has been shown that LAB present in food and beverages can produce this BA [reviewed by 2]. Amines, such as putrescine, can react with nitrite to form nitrosamines, which can have carcinogenic properties and are therefore a potential health hazard to humans [3].

\section{Biomed Central}

(C) 2012 Russo et al.; licensee BioMed Central Ltd. This is an Open Access article distributed under the terms of the Creative Commons Attribution License (http://creativecommons.org/licenses/by/2.0), which permits unrestricted use, distribution, and reproduction in any medium, provided the original work is properly cited. 
One open question is whether BA-producers present in fermented foods and beverages are able to survive in the human GIT and still produce BA. During digestion, the $\mathrm{pH}$ of the human gastric environment can decrease to values below $\mathrm{pH} 2$. Some LAB possess high resistance to gastrointestinal stress and frequently have adhesive properties that allow them to colonize the intestinal tract [15]. We have recently shown that the dairy tyramineproducer Enterococcus durans 655 was significantly resistant to in vitro conditions which mimicked the human GIT and, it was able to synthesize BA under GIT stress conditions [16]. Possession of a functional tyramine biosynthetic pathway enhanced the binding of E. durans to Caco-2 human intestinal cells [16].

To further investigate this issue, we report here experiments with the wine strain Lactobacillus brevis IOEB 9809 [17], which possesses both the tyrosine decarboxylation and the agmatine deimination pathways $[13,18,19]$. Four genes ( $t d c$ operon) involved in tyrosine production have been identified in L. brevis IOEB 9809: a putative tyrosyl tRNA synthetase, a tyrosine decarboxylase, a tyrosine-tyramine exchanger and a $\mathrm{Na}+/ \mathrm{H}+$ antiporter. The gene cluster for agmatine catabolism lies immediately downstream of the $t d c$ operon, and its genes encode a putrescine transcarbamylase, an agmatine/putrescine exchanger, two putative agmatine deiminases (one of which, aguA1, encodes a catalytically active enzyme), a carbamate kinase and a putative transcriptional regulator (AguR). The presence of a functional substrate/product transmembrane exchanger in both systems suggests that the pathways may be involved in $\mathrm{pH}$ homeostasis.

In this study we have subjected L. brevis IOEB 9809 to an in vitro system, which partially mimics physical stresses in the human gastrointestinal tract, to determine if BA synthesis occurs. Transcriptional analysis was used to detect any enhancement of tyrosine decarboxylase $(\operatorname{tyr} D C)$ and agmatine deiminase $(a g u A 1)$ gene expression. Furthermore, the adhesion of the IOEB 9809 strain to human epithelial intestinal cells was investigated and BA production in bacteria-human cells co-cultures was measured.

\section{Results and discussion}

\section{Behaviour of $L$. brevis IOEB 9809 under simulated upper digestive tract conditions}

To test for BA production and the influence of active BA biosynthetic pathways on bacterial survival IOEB 9809 was grown to approximately $8 \times 10^{8} \mathrm{CFU} \mathrm{mL}^{-1}$ in MRS medium in the absence or presence of $10 \mathrm{mM}$ tyrosine or $4.38 \mathrm{mM}$ agmatine sulphate or both (these concentrations were previously found to be optimal for BA production; data not shown). Then, the cultures were subjected to conditions that simulated some of the more important conditions of the human upper digestive tract, including treatment with lysozyme at $\mathrm{pH} 6.5$ (simulating saliva) and at a range of low $\mathrm{pH}$ in the presence of pepsin (simulating gastric stress). Acidity within the human stomach during digestion is in the range $\mathrm{pH}$ 1.3-3.5 which corresponds to the range of maximum activity of pepsin [20]. However, during food ingestion, and depending on the food matrix, bacteria can be exposed to a broader $\mathrm{pH}$ gradient. Therefore, during gastric treatment the bacteria were exposed to a decreasing range of $\mathrm{pH}$ from 5.0 to 1.8 , which we have previously used for testing of probiotic and lactic acid bacteria [16,21-23].

BA production was quantified by reverse-phase HPLC of culture supernatants, and cell viability was assessed by plate counting. Under all conditions, production of tyramine and putrescine was observed in the presence of the corresponding precursor (Table 1). The bacterium was sensitive to all conditions tested (Figure 1). The saliva simulation reduced the survival of IOEB 9809 to $34 \%$ in the control samples. A higher survival (62\%) was observed in the presence of tyrosine, which was enhanced (69\%) when agmatine was included in the assay. This survival-aiding influence of tyrosine was not previously observed with the dairy tyramine-producer $E$. durans 655 [16], and as far as we know this is the first report indicating that functional BA biosynthetic pathways or presence of their precursors contribute to diminish damage of cell wall by lysozyme. The mechanism for this is unclear.

The pattern of increased survival was also detected under gastric simulation at $\mathrm{pH} 5.0$ and 4.1. Below $\mathrm{pH}$ 4.1 reduction of viability was marked. This reduction was qualitatively confirmed by confocal microscopy, after bacterial staining with SYTO9 and propidium iodide. An example is depicted in Figure 2. In cultures subjected to gastric stress at $\mathrm{pH} 4.1$ a mixed population of green (alive) and red (non-viable cells) were detected. Moreover, the proportion of green cells was low in the absence of precursors (Figure 2A) and progressively increased in the presence of agmatine (Figure 2B), tyrosine (Figure 2C) and both BA precursors (Figure 2D). In addition, in untreated cultures only green cells were detected whereas only a few cells, most of them red (non-viable) were observed after exposure to gastric conditions at very acidic $\mathrm{pH} 1.8$ (results not shown). The tyrosine decarboxylase of IOEB 9809 has an optimal $\mathrm{pH}$ of 5.0 and is active between $\mathrm{pH}$ 3.0-7.0 in cell suspension [24]. In agreement we found the highest levels of tyramine production under gastric stress in the range $\mathrm{pH}$ 3.0-5.0 (Table 1). Interestingly, significant concentrations of tyramine $\left(50 \mu \mathrm{M}, 2.5 \mathrm{nmol} \mathrm{mL} \mathrm{min}^{-1}\right)$ and putrescine $\left(13 \mu \mathrm{M}, \quad 0.65 \mathrm{nmol} \mathrm{mL}^{-1} \mathrm{~min}^{-1}\right.$ ) were observed in the samples exposed to $\mathrm{pH} 1.8$ in the 
Table 1 Production of tyramine and putrescine by L. brevis IOEB 9809 in the presence of diverse BA precursors

\begin{tabular}{lcccc}
\hline BA precursor & Agmatine & Tyrosine & \multicolumn{2}{c}{ Agmatine +Tyrosine } \\
\hline BA produced & Put $(\mu \mathrm{M})$ & Tym $(\mu \mathrm{M})$ & Put $(\mu \mathrm{M})$ & Tym $(\mu \mathrm{M})$ \\
Saliva & $22.33 \pm 2.52^{\mathrm{a}}$ & $26.08 \pm 0.13^{\mathrm{a}}$ & $32.66 \pm 2.76^{\mathrm{ab}}$ & $56.46 \pm 3.06^{\mathrm{ad}}$ \\
G pH 5.0 & $37.67 \pm 3.06^{\mathrm{b}}$ & $78.29 \pm 1.07^{\mathrm{b}}$ & $57.27 \pm 11.69^{\mathrm{c}}$ & $194.63 \pm 9.69^{\mathrm{e}}$ \\
G pH 4.1 & $36.00 \pm 3.00^{\mathrm{b}}$ & $122.30 \pm 2.55^{\mathrm{c}}$ & $39.22 \pm 5.01^{\mathrm{b}}$ & $174.46 \pm 8.07^{\mathrm{f}}$ \\
G pH 3.0 & $11.59 \pm 0.56^{\mathrm{d}}$ & $82.18 \pm 1.10^{\mathrm{bc}}$ & $15.33 \pm 1.05^{\mathrm{da}}$ & $113.87 \pm 5.27^{\mathrm{c}}$ \\
G pH 2.1 & $10.54 \pm 0.46^{\mathrm{d}}$ & $74.21 \pm 1.07^{\mathrm{bd}}$ & $14.32 \pm 1.08^{\mathrm{da}}$ & $76.10 \pm 3.53^{\mathrm{b}}$ \\
G pH 1.8 & $11.21 \pm 0.45^{\mathrm{d}}$ & $62.26 \pm 1.09^{\mathrm{d}}$ & $13.42 \pm 1.01^{\mathrm{da}}$ & $50.91 \pm 2.36^{\mathrm{ad}}$ \\
\hline
\end{tabular}

Tyramine (Tym) and putrescine (Put) production were detected by RP-HPLC during the saliva and gastric stress simulation in presence of 10 mM tyrosine, 4.38

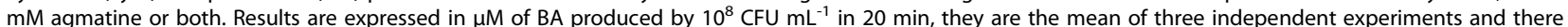
are corrected for the CFU added to the experiment. Putrescine and tyramine were below the detection limits ( $2 \mathrm{nM}$ and $2.5 \mathrm{nM})$ in the uninoculated MRS and in absence of the corresponding BA precursor. Differences were assessed by Anova test. Different superscript letters associated with values of the same BA indicate statistically significant differences $(P<0.05)$.

presence of the two BA precursors, even though only $1.7 \times$ $10^{1} \mathrm{CFU} \mathrm{mL}{ }^{-1}$ were detected at the end of the assay. This suggests that the inoculum was able to synthesise a substantial quantity of tyrosine decarboxylase during the test before cell death and lysis occurred, and that probably the tyrosine decarboxylase remained substantially active in the dead cells and cell lysate. The tyrosine decarboxylase of IOEB 9809 is active in a range of $\mathrm{pH} 2.0-8.0$ in cell-free extract [24].
When we simulated the gastric environment, in addition to the action of lysozyme, the bacteria were subjected to multiple stress stimuli: decreasing $\mathrm{pH}$, proteolytic activity of pepsin and heat shock at $37^{\circ} \mathrm{C}$. Griswold et al. [25] (2006), propose that the agdi operon could be part of a general stress response pathway in Streptococcus mutans. The agmatine deimination, by forming ammonia and providing ATP, would result in mild deacidification of the medium, metabolic energy

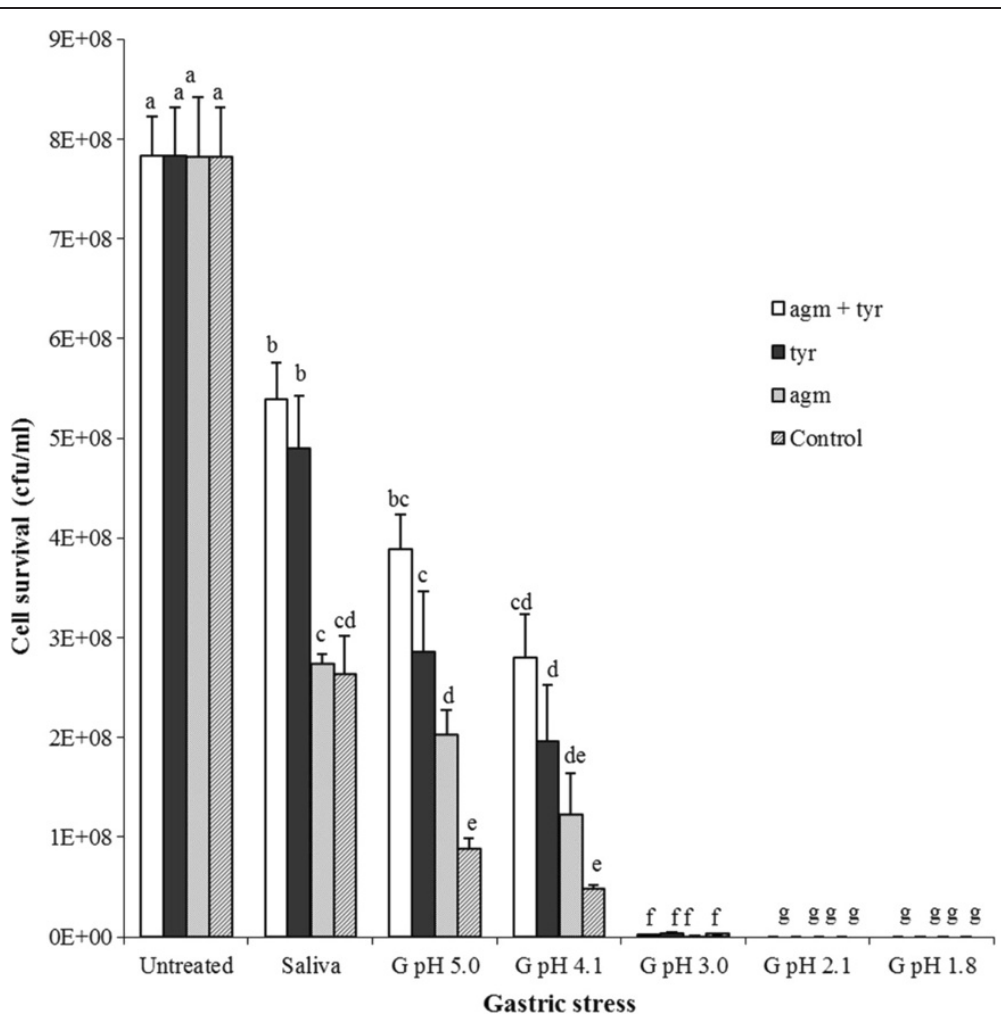

Figure 1 Response of $L$. brevis IOEB 9809 to saliva and gastric stresses. The salivary (saliva) and gastric (G) stresses were applied to bacteria in MRS (control), or in medium supplemented by addition of $4.38 \mathrm{mM}$ agmatine (agm), $10 \mathrm{mM}$ tyrosine (tyr), or both (agm + tyr). The values are the average of 3 independent experiments. Vertical bars represent the standard deviation. Differences were assessed by Anova test with all samples. Different superscript letters associated with values of CFU mL ${ }^{-1}$ indicate statistically significant differences $(P<0.05)$. 

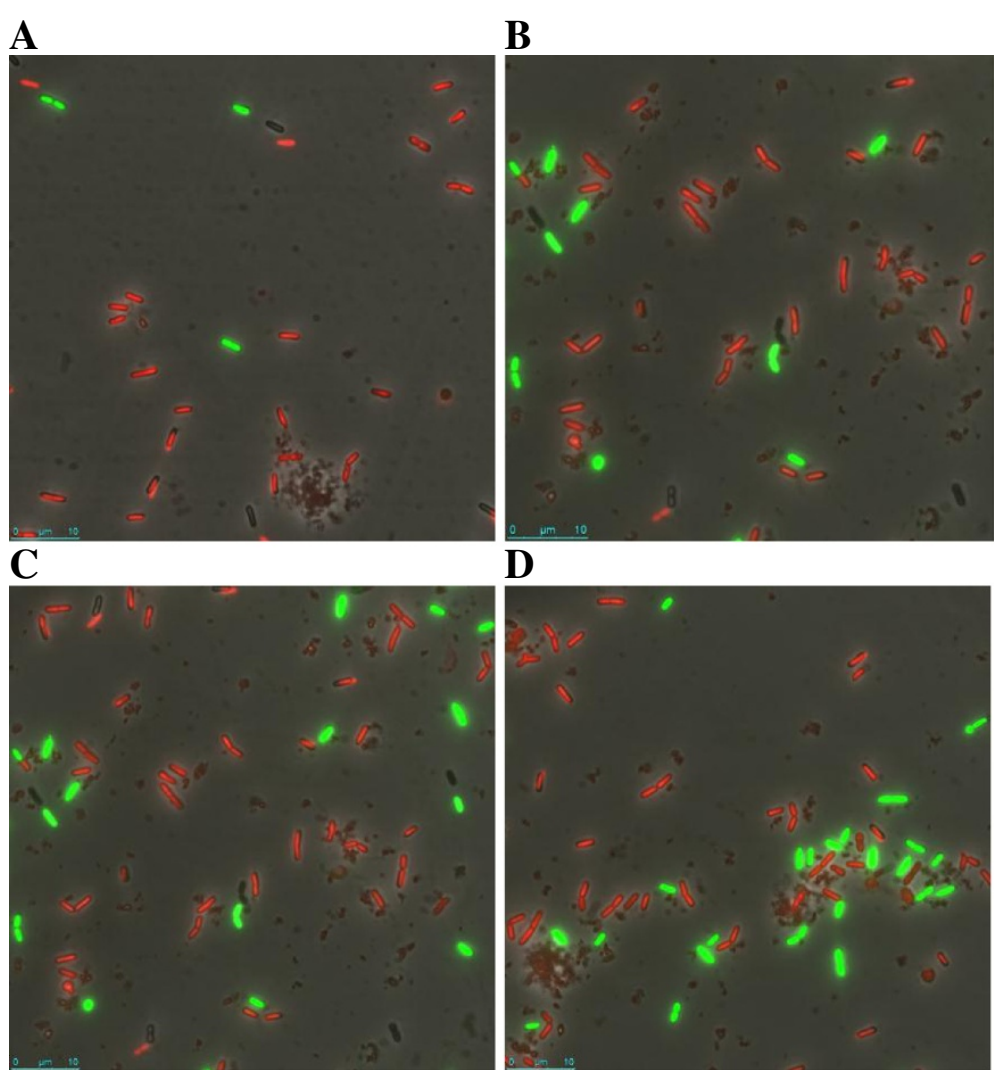

D

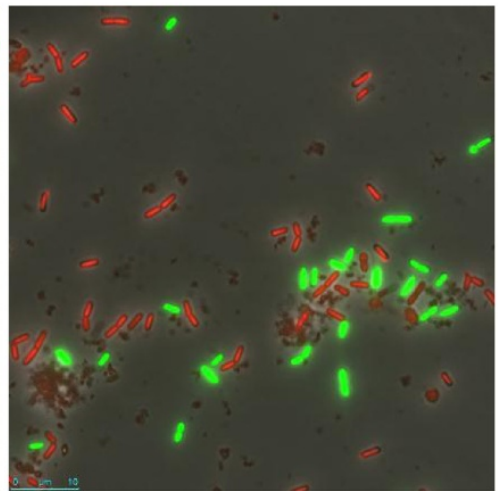

Figure 2 Detection of live-dead bacteria by confocal microscopy. Observation by confocal microscopy of L. brevis IOEB 9809 after gastric stress to $\mathrm{pH} 5.0$ in absence of BA precursors (A) or in presence of: agmatine (B), tyrosine (C) or agmatine plus tyrosine (D). Green cells represent live bacteria, while red cells are bacteria with damaged membrane.

release and degradation of toxic compounds [25]. Here, the maximum levels of putrescine (around $40 \mu \mathrm{M}$ ) production by $L$. brevis were observed between $\mathrm{pH}$ 5.0-4.1 for cultures supplemented with agmatine (Table 1), which accords with that reported for Lactobacillus hilgardii at $\mathrm{pH} 4.5$ [26] and for Streptococcus mutans at $\mathrm{pH}$ 4.0 [27].

There is evidence suggesting that BA production enables producing organisms to survive at low $\mathrm{pH}$ [28]. Our results show that at $\mathrm{pH} 5.0$ the presence of agmatine, tyrosine or both precursors enhanced the cell survival two-, three- and four-fold respectively compared to controls (Figure 1). At pH 4.1, the beneficial effect on viability was even more pronounced (4- and 6-fold increase in the presence of tyrosine, and tyrosine plus agmatine); however, it has no beneficial effect at more acidic pHs (Figure 1). Thus, it seems that the beneficial effect of the putrescine and tyramine biosynthetic pathways is restricted only to mild acidic conditions.

\section{Transcriptional analysis of tyrDC and aguA1 genes}

The above results indicated that an increase of BA production occurred under saliva and mild gastric stresses, presumably due either to a physiological effect, or to increased gene expression. Therefore, expression of the tyrDC and aguA1 genes, encoding tyrosine decarboxylase and agmatine deiminase, the key enzymes for tyrosine and putrescine synthesis $[13,24]$, were analyzed in exponential phase cultures prior to, or after, exposure to saliva and gastric stresses at $\mathrm{pH} 5.0$ or 4.1, in the presence or absence of BA precursors. Transcriptional levels were calculated relative to the mRNA levels of an unstressed sample for each condition tested, using the expression of the tuf gene as internal control (see Methods). A similar pattern of expression for both genes was observed in unstressed and stressed samples for all conditions tested (Figure 3). mRNAs corresponding to $\operatorname{tyr} D C$ (Figure $3 \mathrm{~A}$ ) or aguA1 (Figure 3B) were induced only if the bacterium had been challenged with tyrosine or agmatine. Under all conditions tested, higher levels of $\operatorname{tyr} D C$ and aguA1 transcripts were detected when both BAs precursors were present (approximately 9-fold increase in unstressed cultures and 11fold under gastric stress at $\mathrm{pH}$ 4.1). Furthermore, it should be noted that transcriptional levels of the two genes in the control cultures were not reduced under conditions of gastric stress. 

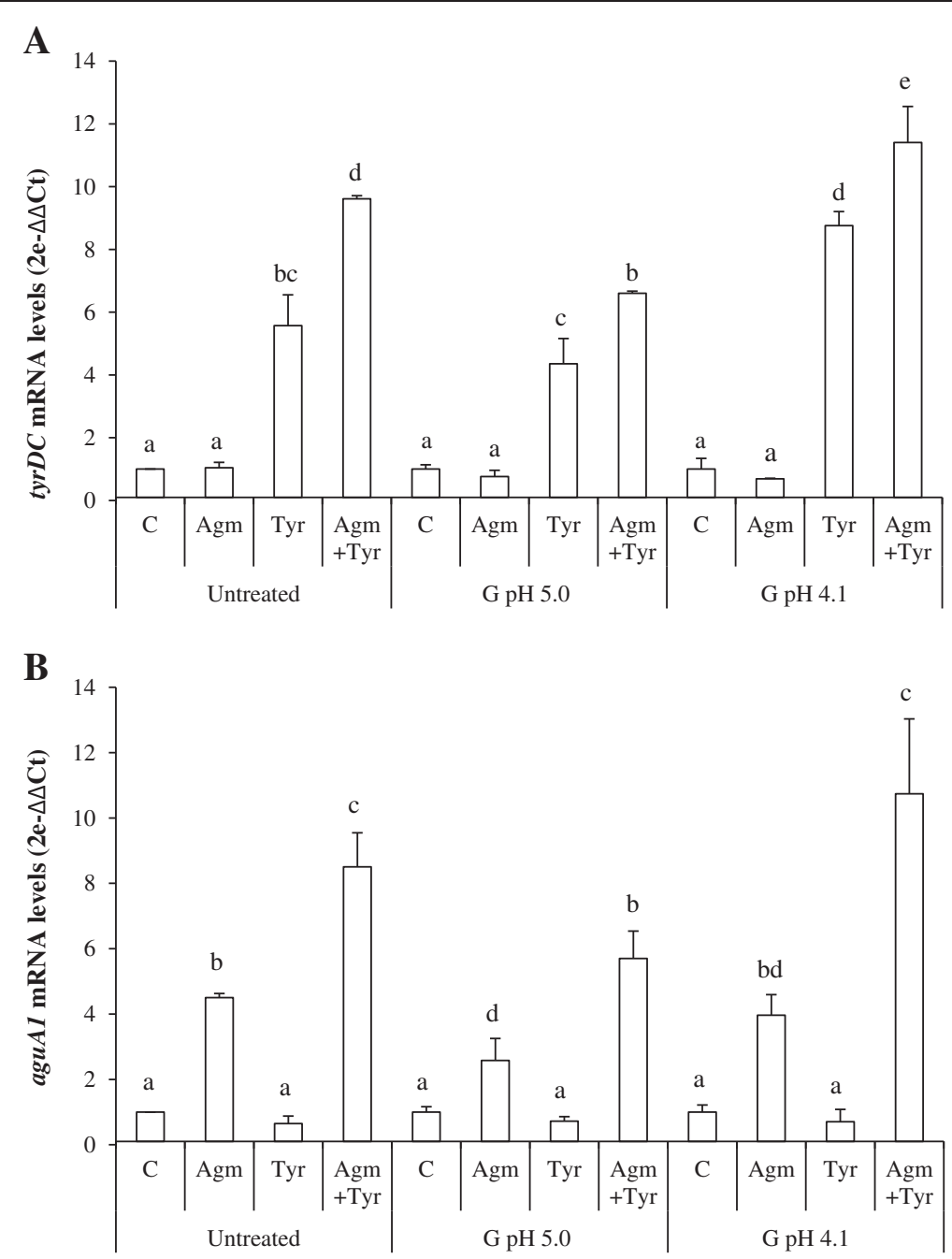

Figure 3 Relative expression of $\boldsymbol{t d c}(\mathbf{A})$ and $\operatorname{aguA} \mathbf{1}$ (B) genes. Total RNAs were extracted at mid-exponential phase prior treatment (untreated) and after saliva plus gastric stress at either pH 5.0 (G pH 5.0) or pH 4.1 ( $\mathrm{G} \mathrm{pH} \mathrm{4.1),} \mathrm{in} \mathrm{presence} \mathrm{of} 4.38 \mathrm{mM}$ agmatine, $10 \mathrm{mM}$ tyrosine or both, or in their absence. mRNA levels were quantified as n-fold differences by comparing to RNA samples from their respective unstressed cultures (mRNA value=1). Relative levels of expression in absence of BA-precursors for untreated/G pH 5.0/G pH 4.1 were 1/0.7/0.4 in (A) and 1/0.6/0.3 in (B). Each experiment was performed in triplicate. Vertical bars represent the standard deviation. Differences were assessed by Anova test. Different superscript letters associated with values of either tyrDC or aguA1 mRNA levels indicate statistically significant differences $(P<0.05)$.

These results show a transcriptional induction of $\operatorname{tyr} D C$ and aguA1 mediated by the respective BAprecursors under saliva and gastric stresses similar to that previously observed for IOEB 9809 under wine stress conditions [29]. The increased transcription of both genes in the presence of tyrosine plus agmatine strongly suggests a previously undetected synchronous regulation of both BA pathways, which deserves further investigation.

Considering the overall results pertaining to BA production (Table 1), cell survival (Figure 1) and transcriptional analysis (Figure 3), it appears that induction of BA biosynthetic pathway at the transcriptional level by the presence of the BA precursor under mild gastric conditions results in increase of the bacterial survival.

\section{Behaviour of L. brevis IOEB 9809 in the presence of human Caco-2 intestinal epithelial cells}

Our results revealed that at $\mathrm{pH} 4.1$ there is an approximately 35\% survival of IOEB 9809 (in the presence of agmatine and tyramine) and an approximately $0.4 \%$ survival at pH 3.0 (Figure 1). It is therefore possible, assuming ingestion of a high concentration IOEB 9809, that viable cells could be released from the stomach at the upper end of its normal $\mathrm{pH}$ range. Therefore, binding ability as well as production of BAs during coincubation of IOEB 9809 with Caco-2 cells was analyzed. Caco-2 cells are human colonic adenocarcinoma cells that, after differentiation, have features characteristic of mature small intestine cells [30]. The maximum adhesion levels were obtained within the ratios of 1:100 to 
1:1000 Caco- 2 cells to bacteria after $1 \mathrm{~h}$ incubation, as we have also observed for other LAB and bifidobacteria $[21,23]$. Figure 4 depicts the results obtained with a ratio of $1: 100$, adhesion levels ranged from 2 to $3 \%$ approximately, values similar to the two probiotic bacteria tested Lactobacillus acidophilus La-5 and Bifidobacterium animalis subsp. lactis BB-12 (Figure 4). Moreover, we did not detect any statistically significant influence of the BA precursors on the adhesion capability of L. brevis (result not shown). Logically, the ability to adhere to the epithelium of the small intestine could be an aid to colonisation.

In addition, the bacteria could synthesize BA in the intestinal environment, and to test this hypothesis, the production of BA by IOEB 9809 in the presence of Caco-2 cells was investigated. The bacterium was exposed to the cells at a ratio of 1:1000 in DMEM medium for $8 \mathrm{~h}$, in the presence or absence of the BA precursors, and the supernatants were analyzed by HPLC. Both BA were detected only when the precursors were present (Table 2 and data not shown). Levels of tyramine $(180 \mu \mathrm{M})$ slightly increased in the presence of both BAs precursors $(230 \mu \mathrm{M})$, and high levels of putrescine (1330-1980 $\mu \mathrm{M})$ were observed irrespectively of tyrosine availability. Enterocytes can both synthesize and take up putrescine [31], however, there was little production of the $\mathrm{BA}$ in the absence of the bacterium (Table 2), although a high consumption of agmatine was detected (results not shown) (Table 2), in agreement with the ability of epithelial cells to take up this compound without further metabolism [32]. Moreover, the absence of the human cells had little effect on putrescine synthesis by IOEB $9809(1330 \mu \mathrm{M}$ versus $1003 \mu \mathrm{M})$, in the presence of agmatine and tyrosine. In assays supplemented only with agmatine, a significantly lower level of putrescine was detected in samples containing only bacterial cells $(190 \mu \mathrm{M}$ versus $1980 \mu \mathrm{M})$. These results indicate that the presence of Caco- 2 cells overcomes the need of tyrosine for full induction of the putrescine biosynthetic pathway of IOEB 9809 in DMEM medium. Finally, no synthesis of tyramine by Caco- 2 cells was observed in absence of bacteria and a slight but significant increase of the BA levels was observed in the presence of both precursors when either bacteria $(220 \mu \mathrm{M}$ versus $320 \mu \mathrm{M})$ or co-cultures $(180 \mu \mathrm{M}$ versus $230 \mu \mathrm{M})$ were analyzed.

\section{Comparison of L. brevis IOEB 9809 with Enterococcus durans 655}

In a previous study [16] we studied the behaviour of Enterococcus durans 655 under saliva and gastric stresses as well as in presence of Caco-2 epithelial cells using essentially the same conditions as described in this paper. Our results reveal that the wine L. brevis IOEB 9809, like the dairy E. durans 655 [16], was able to produce tyramine under saliva and gastric stresses as well as in presence of Caco-2 epithelial cells. In addition, L. brevis was able to produce putrescine in all conditions tested. However, unlike E. durans [16] an increase of bacterial survival under saliva and mild gastric $(\mathrm{pH}$ 5.0-4.0) stresses correlated with transcriptional activation of both BA biosynthetic pathways. Moreover, we found that adhesion levels of $L$. brevis to Caco-2 cells were between $2 \%$ and $3 \%$, similar to that detected for E. durans 655 (2\% or $6 \%$ in absence or presence of tyrosine) [16]. We did not detect any influence of the BA biosynthetic pathways on $L$. brevis adhesion capability. However, we have only observed for $L$. brevis an increase of putrescine production in co-cultures of bacteria and epithelial human cells. Thus, it seems that the role of the BA biosynthetic pathways of Lactobacillus in the human GIT environment differs from that of Enterococcus.

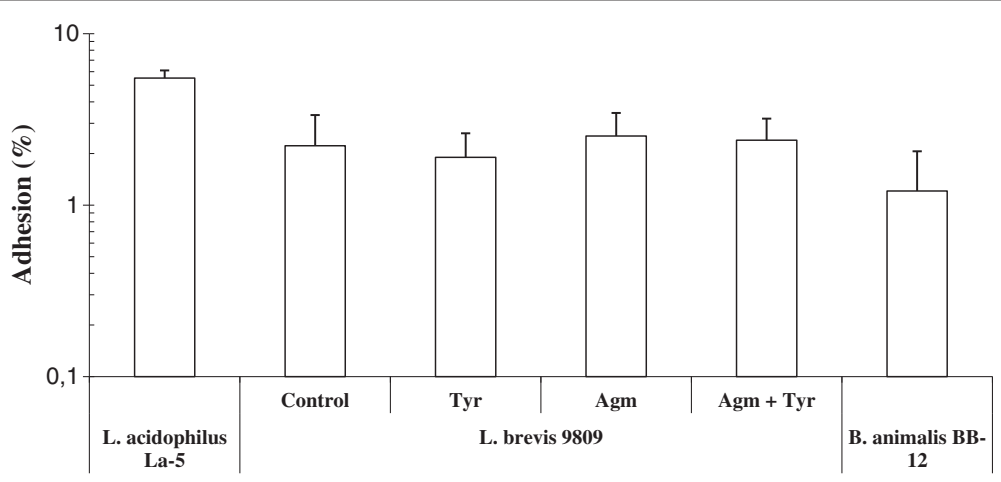

Figure 4 Adhesion levels of Lactobacillus brevis IOEB 9809 to epithelial intestinal cells line. Adhesion levels of L. brevis IOEB 9809, harvested at mid-exponential phase, to Caco-2 cells were measured after exposure in DMEM medium supplemented or not, with tyrosine, agmatine or both. Percentage of adhesion was normalized by using unwashed wells as control and compared with adhesion levels of probiotic strains L. acidophilus La-5 and B. animalis subsp. lactis BB-12. Each experiment was performed in triplicate. Vertical bars represent the standard deviation. 
Table 2 Production of biogenic amines in presence of epithelial cells

\begin{tabular}{|c|c|c|c|c|c|c|}
\hline \multirow[t]{2}{*}{ Precursors added } & \multicolumn{2}{|c|}{ Bacteria +Human cells } & \multicolumn{2}{|c|}{ Bacteria } & \multicolumn{2}{|c|}{ Human cells } \\
\hline & Put $(\mu \mathrm{M})$ & Tym $(\mu \mathrm{M})$ & Put $(\mu \mathrm{M})$ & Tym & Put $(\mu \mathrm{M})$ & $\operatorname{Tym}(\mu \mathrm{M})$ \\
\hline $\operatorname{Agm}(4.3 \mathrm{mM})$ & $1980 \pm 170^{a}$ & ND & $190 \pm 80^{c}$ & ND & $10 \pm 2^{d}$ & ND \\
\hline Tyr (10 mM) & ND & $180 \pm 9^{a}$ & ND & $220 \pm 1^{\mathrm{ab}}$ & ND & ND \\
\hline $\operatorname{Tyr}(10 \mathrm{mM})+\mathbf{A g m}(4.3 \mathrm{mM})$ & $1330 \pm 420^{\mathrm{a}}$ & $230 \pm 9^{a b}$ & $1003 \pm 41^{b}$ & $320 \pm 80^{b}$ & $7 \pm 0^{d}$ & ND \\
\hline
\end{tabular}

Tyramine (Tym) and putrescine (Put) were detected by RP-HPLC in samples containing DMEM medium supplemented or not with $10 \mathrm{mM}$ tyrosine, $4.38 \mathrm{mM}$ agmatine or both precursors, after $8 \mathrm{~h}$ incubation. Cells present during the assay: Bacteria + Human cells: L. brevis IOEB 9809 (10 ${ }^{8}$ CFU mL $\left.\mathrm{mL}^{-1}\right)$ and Caco-2 cells (10 cells $\left.\mathrm{mL}^{-1}\right)$; Bacteria: L. brevis IOEB $9809\left(10^{8} \mathrm{CFU} \mathrm{mL} \mathrm{L}^{-1}\right)$ and Human cells: Caco-2 cells $\left(10^{5}\right.$ cells $\left.\mathrm{mL}^{-1}\right)$. Results are expressed as the mean \pm standard deviation of three independent experiments. ND: not detected. Detection limits: for Put $>2 \mathrm{nM}$ and for Tym $>2.5 \mathrm{nM}$. Putrescine and tyramine were below the detection limits in the DMEM medium as well as in samples containing either bacteria or Caco-2 cells in absence of the corresponding BA precursor. Differences were assessed by Anova test. Different superscript letters associated with values of the same BA indicate statistically significant differences $(P<0.05)$.

\section{Potential impact of L. brevis IOEB 9809 on human health}

With regard to the potential impact of L. brevis on human health, our results indicate that during transit through the stomach (1h $40 \mathrm{~min}$ in our assay) as well as in contact with Caco- 2 cells $(8 \mathrm{~h})$ the bacteria could produce around $0.5 \mathrm{mM}$ tyramine $\left(87 \mathrm{mg} \mathrm{L}^{-1}\right)$. This should not be harmful for healthy individuals, since an average of $500 \mathrm{mg}$ of orally administrated tyramine is required to increase systolic blood pressure [33]. However, tyramine can be particularly toxic to patients receiving monoamine oxidase (MAO) inhibitors. Gastrointestinal $\mathrm{MAO}$ is essential for the breakdown of tyramine and it has been reported that as little as $6 \mathrm{mg}$ of tyramine is sufficient to produce hypertension in humans treated with MAO inhibitors [34]. Ethanol also inhibits MAO. Thus the expected low toxic effect due to low levels of tyramine produced by L. brevis during wine fermentation could be potentiated by the simultaneous ingestion of high ethanol content beverages. Moreover, the production of putrescine by this bacterium could be also harmful. The polyamines, including putrescine, play a role in the maturation of the intestine, even when administrated orally [35]. Polyamines administrated orally can act as growth factors with beneficial or detrimental effects, depending on their concentration [36] and there is evidence suggesting that putrescine can cause malignancy in GIT cells [37]. It is estimated that the daily intake of polyamines in the diet is in the range of 350-550 $\mu \mathrm{mol}$. Thus, the amount of putrescine (around $140 \mu \mathrm{M}$ ) produced by L. brevis in $1 \mathrm{~h} 40 \mathrm{~min}$ in the gastric environment seem to be of little concern. However, the 1.3-1.9 $\mathrm{mM}$ production of putrescine in the presence of Caco-2 epithelial cells during $8 \mathrm{~h}$, is more worrying, especially if L. brevis is able to colonize, even transiently, the small intestine.

\section{Conclusions}

L. brevis IOEB 9809 produced both tyramine and putrescine under all conditions in an in vitro model that simulated the normal physiological conditions in the human digestive tract, as well as in the presence of Caco-2 epithelial cells. Under mild gastric stress bacterial survival improved in the presence of BA precursors and a synchronous transcriptional activation of the tyramine and putrescine biosynthetic pathways was detected. These results suggest that BA production may be a mechanism that increases bacterial survival under acid stress. The results also indicate that it may be possible for viable cells of L. brevis IOEB 9809 to pass from the stomach into the duodenum.

L. brevis IOEB 9809 cells were able to adhere to Caco2 cells, which suggests that they may be able to adhere to human intestinal epithelium. However, this would not necessarily guarantee that L. brevis IOEB 9809 would colonise the lower intestine as the impact of competition with other resident microorganisms, and the gut's innate defence mechanisms has not been assessed for this organism. High levels of both BA were observed after exposure of the bacterium to Caco- 2 cells.

\section{Methods}

\section{Bacterial strain}

L. brevis IOEB 9809, isolated from Bordeaux red wine, was obtained from the IOEB strain collection (Institute of Oenology of Bordeaux, ISVV, Villenave d'Ornon, France). The probiotic bacteria Lactobacillus acidophilus LA-5 and Bifidobacterium animalis subps. lactis BB-12 (Chr. Hansen A/S., Hørsholm, Denmark) were also used. All strains were maintained at $-80^{\circ} \mathrm{C}$ in de Man Rogosa Sharpe (MRS) [38] broth (Pronadisa, Madrid, Spain) supplemented with $20 \%$ (vol/vol) glycerol.

\section{Analysis of cell survival under upper digestive tract stress Induction of $B A$ production}

Four cultures of L. brevis IOEB 9809 were grown at $30^{\circ}$ $\mathrm{C}$ in MRS initial pH 6.2. One culture was unsupplemented (uninduced), and the other three were supplemented with $10 \mathrm{mM}$ tyrosine (Sigma-Aldrich, St Louis, MO), or $4.38 \mathrm{mM}$ agmatine sulphate (Sigma-Aldrich, St Louis, $\mathrm{MO})$ or both. These concentrations of BA precursors were optimal for production of BA during bacterial growth (results not shown). Pyridoxal phosphate $0.005 \%$ (wt/vol) final concentration (Sigma-Aldrich, St Louis, MO) was added to all cultures as coenzyme for decarboxylation reactions. All of the above was performed in 
triplicate (12 cultures in total). Cells were harvested in the mid-exponential phase $\left(\mathrm{OD}_{620}=0.8\right.$, approximately $8 \times 10^{8} \mathrm{CFU} \mathrm{mL} \mathrm{m}^{-1}$ ) by centrifugation, and resuspended in the same volume of the corresponding fresh MRS medium.

\section{Digestive tract simulation}

To determine the tolerance to saliva and gastric stresses, we modified a previous method [21]. Each of the 12 resuspended cell samples (above) was dispensed in 7 groups of $2.5 \mathrm{ml}$ aliquots. Group 1 (control) was untreated. Group 2 (saliva simulation) $10 \%$ ( $\mathrm{vol} / \mathrm{vol}$ ) of a sterile electrolyte solution [39] $\mathrm{pH} 6.5$ supplemented with $1 \%$ (wt/vol) lysozyme (Sigma-Aldrich, St Louis, $\mathrm{MO}$ ) was added to each aliquot, and they were incubated for $5 \mathrm{~min}$ at $37^{\circ} \mathrm{C}$ with shaking. Groups 3-7 (gastric environment simulation) $0.3 \% \quad(\mathrm{wt} / \mathrm{vol}$ ) pepsin (Sigma-Aldrich, St Louis, MO) was added to saliva simulation followed by acidification with $1 \mathrm{M} \mathrm{HCl}$ to $\mathrm{pH} 5.0$, 4.1, 3.0, 2.1 or 1.8 respectively. All aliquots subjected to gastric stress were independently incubated for $20 \mathrm{~min}$, at $37^{\circ} \mathrm{C}$ with shaking. After the treatments, the bacteria were collected by centrifugation $(8.000 \times \mathrm{g}, 8 \mathrm{~min})$ and cell survival was determined by plate counting on MRS agar. Supernatants were filtered $(0.2 \mu \mathrm{m}$ filters, VWR international, West Chester, PA) and analyzed by reverse-phase high-performance liquid chromatography (RP-HPLC) (see below) for tyramine and putrescine.

\section{Cell culture and in vitro adhesion assay}

The Caco- 2 cell line was obtained from the cell bank of the Centro de Investigaciones Biológicas (Madrid, Spain), and was grown and differentiated as previously described [23]. For the adhesion assay, Dulbecco's Modified Eagle Medium (DMEM) with L-glutamine $(580 \mathrm{mg}$ $\left.\mathrm{L}^{-1}\right)$, D-glucose $\left(4500 \mathrm{mg} \mathrm{L}^{-1}\right)$ and sodium pyruvate (110 $\left.\mathrm{mg} \mathrm{L}^{-1}\right) \mathrm{pH} 8.2$ was prepared without L-tyrosine, according to the Invitrogen formulation. DMEM medium was supplemented with the same concentration of L-tyrosine and agmatine sulphate as used for the gastrointestinal experiments. In the adhesion assay experiments, bacteria grown in MRS to the mid-exponential phase $\left(\mathrm{OD}_{620}=\right.$ $0.8)$ as for BA induction, were centrifuged $(10.000 \mathrm{x} \mathrm{g}$, $10 \mathrm{~min}$ ), washed once with cold phosphate-buffered sa-

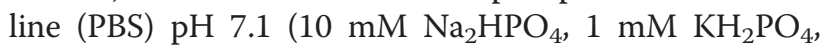
$140 \mathrm{mM} \mathrm{NaCl}, 3 \mathrm{mM} \mathrm{KCl}$, all purchased from Merck, Darmstadt, Germany) and resuspended in the same DMEM medium supplemented, or not, with tyrosine, agmatine or both. Bacterial suspensions were added to Caco-2 intestinal cells in a final volume of $0.1 \mathrm{~mL}$ and a final concentration of $1.25 \times 10^{7} \mathrm{CFU} \mathrm{mL}^{-1}$ (ratio 1:100, Caco-2 cells to bacteria) and incubated at $37^{\circ} \mathrm{C}$ for $1 \mathrm{~h}$. Unbound bacteria were then removed by washing three times with $0.2 \mathrm{~mL}$ of $\mathrm{PBS}$ at $\mathrm{pH}$ 7.1. Some wells, unwashed, were used as control. Cell cultures were then resuspended in $0.1 \mathrm{~mL}$ of PBS and detached by adding $0.1 \mathrm{ml}$ of $0.05 \%$ trypsin-EDTA (Gibco, Carlsbad, CA). After incubation at $37^{\circ} \mathrm{C}$ for $10 \mathrm{~min}$, the detachment reaction was interrupted by adding $0.1 \mathrm{~mL}$ of cold PBS. The number of total and adhered bacteria was determined by serial dilution and quantitation on agar plates as for viable counts. The adhesion percentage was calculated by comparing the number of CFU from three washed wells with those from control wells. Every experiment was performed in triplicate.

\section{RP-HPLC determination of BA}

Pre-column dabsyl chloride manual derivatisation was performed for BA detection. The derivatisation reaction was carried out as described by Krause et al. [40]. $10 \mu \mathrm{l}$ of the dabsylated supernatants were used for injection. HPLC analysis was performed using an Alliance 2795 system (Waters, Milford, MA) equipped with a Waters Nova-Pack $\mathrm{C}_{18}$ column $(150 \times 3.9 \mathrm{~mm} 4 \mu \mathrm{m}$ particle size). Dabsylated amino acids and amines were eluted using the gradient described by Krause et al. [40]. Detection was carried out by a Waters 2996 Photodiode array detector at $436 \mathrm{~nm}$.

\section{RNA extraction and Real Time PCR analysis}

Transcriptional analysis was performed after $20 \mathrm{~min}$ gastric stress simulation. Control and samples mimicking gastric stress at $\mathrm{pH}$ 5.0, were analyzed in the presence or absence of biogenic amine precursors. Total RNAs were extracted from $2 \times 10^{9}$ cells using the FastRNA pro blue kit (Qbiogene, Montreal, QC) following the manufacturer's instructions. Cells were lysed mechanically with a Hybaid Ribolyser for $30 \mathrm{~s}$. The RNAs' quantity and quality was determined by spectrophotometry, and their integrity was assessed by visualization of the rRNA bands on $1.2 \%$ agarose gels. Absence of chromosomal DNA was confirmed by quantitative real-time PCR.

cDNAs were synthesized using $0.8 \mu \mathrm{g}$ of total RNA and Quantitect Reverse Transcription (Qiagen, Hilden, Germany) which included a DNase treatment and reverse transcription.

Primers for real time PCR were designed to have a length around 20 bases, a GC content of approximately $50 \%$ and a $\mathrm{Tm}$ around $60^{\circ} \mathrm{C}$. OligoPerfect Designer software (Invitrogen, Carlsbad, CA) was used to select primers sequences. Secondary structures and dimer formation were predicted using Oligo Analyzer 3.0 software (Integrated DNA Technologies, Coralville, IA). Primers were purchased from Sigma-Aldrich (St Louis, MO).

Real time PCR was performed using an Applied Biosystems 7300 Real-Time PCR System. The tuf gene of $L$. brevis, encoding elongation factor $\mathrm{Tu}$, was used as internal control for the analysis of $\operatorname{tyr} D C$ and aguA1 genes 
expression, as previously described for Streptococcus thermophilus [41]. Standard curves for both the internalcontrol and target genes were obtained by amplifying serial dilutions (ratio, 1:10) of the target sequences. Additionally, data were normalized in function of the amount of total RNA, according to Torriani et al. [42].

The amplifications were carried out in $20 \mu \mathrm{l}$ reactions, by adding $5 \mu \mathrm{l}$ of 1:20 diluted cDNA, to a real-time PCR mix containing Power SYBR Green PCR Master Mix (Applied Biosystems, Foster City, CA), according to the manufacturer's instructions, and $100 \mathrm{nM}$ of each primer. The tyrDC (EMBL accession number LVIS_2213) specific cDNA was amplified with the TDC_F (5'-TGAGAAGGG TGCCGATATTC- $\left.3^{\prime}\right)$ forward and the TDC_R $\left(5^{\prime}\right.$-GCAC CTTCCAACTTCCCATA-3') reverse primers. The aguA1 (EMBL accession number LVIS_2208) specific cDNA was amplified with the AGUA1_F (5'-TCTTGAAAATGCGA CAGACG- $3^{\prime}$ ) forward and the AGUA1_R (5'-TCCAA CGTAGCCTGAGCTTT-3') reverse primers. The TUF_F (5'-AGGCGACGAAGAACAAGAAA- ${ }^{\prime}$ ) forward and the TUF_R (5'-CGATACGACCAGAAGCAACA-3') reverse primers were used to amplify the tuf (EMBL accession number LVIS_1389) specific cDNA.

Thermal cycling was as follows: initial denaturing at $95^{\circ} \mathrm{C}$ for $5 \mathrm{~min}$ followed by 35 cycles at $95^{\circ} \mathrm{C}$ for $15 \mathrm{~s}$ and $60^{\circ} \mathrm{C}$ for $35 \mathrm{~s}$. The amplicons' lengths were $141 \mathrm{bp}$, $240 \mathrm{bp}$ and $159 \mathrm{bp}$ for the tyrDC, aguA1 and tuf genes respectively and their specificity was checked by melting curve analysis.

A threshold cycle value (CT) was determined with a base line settled automatically. The relative expression level of genes was calculated by the $2^{-\Delta \Delta c t}$ method, using unstressed, and unsupplemented with BA precursors, total RNA as calibrator. The relative expression of $t y r D C$ and aguA1 during the other experimental conditions was quantified as $\mathrm{n}$-fold differences with respect to the calibrator.

Real-time PCRs were performed in duplicate for each sample of cDNA, including a negative control in each run. Data were expressed as the mean of three independent experiments.

\section{Confocal laser scanning microscope}

Samples from each gastric stress condition were analyzed by confocal laser scanning microscopy (model TCS-SP2AOBS, Leica Microsystems GmbH, Wetzlar, Germany), after staining with SYTO9 and propidium iodide (LIVE/ DEAD $^{\circledR}$ BacLight ${ }^{\mathrm{m}}$ bacterial viability kit, Molecular Probes, Inc. AA Leiden, The Netherlands) to differentiate the cells as a function of compromised membranes. Confocal illumination was provided with a X63 magnification objective and numerical aperture of $1.40-0.60$ and by Argon laser (488 $\mathrm{nm}$ laser excitation) with a long pass 520-565 nm filter (for green emission) and long pass 630-685 nm filter (for red emission). Image analysis was performed using FRET and FRAP software (Leica Microsystems $\mathrm{GmbH}$, Wetzlar, Germany).

\section{Statistical analysis}

Anova statistical tests were used to evaluate the consistency of the data.

\section{Abbreviations}

Agm: Agmatine; BA: Biogenic amines; GIT: Gastro intestinal tract; LAB: Lactic acid bacteria; RP-HPLC: Reverse-phase high-performance liquid chromatography; Tym: Tyramine; Tyr: Tyrosine; Put: Putrescine.

\section{Authors' contributions}

PR carried out the transcriptional analysis, help to perform the in vitro Gl tract system and drafted the manuscript. AR and MF carried out the biogenic amines detection and quantification and performed the statistical analysis. PFP set up the in vitro Gl tract, confocal microscope analysis and the adhesion assay experiments. GS, PL and PaLu participated in the design of the study, coordination and helped to draft the manuscript. All authors read and approved the final manuscript.

\section{Acknowledgements}

We thank Dr Stephen Elson for critical reading of the manuscript. This work was supported by the EU commission in the framework of the BIAMFOOD project (Controlling Biogenic Amines in Traditional Food Fermentations in Regional Europe FP7- project number 211441).

\section{Author details}

${ }^{1}$ Department of Molecular Microbiology and Infection Biology, Centro de Investigaciones Biológicas, C.S.I.C., Ramiro de Maeztu 9, Madrid 28040, Spain. ${ }^{2}$ Department of Agriculture, Food and Environment Sciences, University of Foggia, Via Napoli 25, Foggia 71100, Italy. ${ }^{3}$ UMR Enologie, INRA, ISW, Université de Bordeaux, 210 chemin de Leysotte, CS50008, Villenave d'Ornon 33882, France. ${ }^{4}$ Instituto de Productos Lácteos de Asturias, CSIC, Carretera de Infiesto s/n, Villaviciosa, Asturias 33300, Spain.

Received: 13 August 2012 Accepted: 18 October 2012

Published: 31 October 2012

\section{References}

1. Silla Santos MH: Biogenic amines: their importance in food. Int J Food Microbiol 1996, 29:213-231.

2. Ladero V, Calles-Enríquez M, Fernández M, Alvarez MA: Toxicological effects of dietary biogenic amines. Curr Nutr Food Sci 2010, 6:145-156.

3. Spano G, Russo P, Lonvaud-Funel A, Lucas P, Alexandre H, Grandvalet C, Coton E, Coton M, Barnavon L, Bach B, Rattray F, Bunte A, Magni C, Ladero $\checkmark$, Alvarez MA, Fernández M, López P, Fernández de Palencia P, Corbí AL, Trip H, Lolkema JS: Biogenic amines in fermented foods. Eur J Clin Nutr 2010, 64:95-100

4. Ten Brink B, Damink C, Joosten HML, Huis in't Veld JH: Occurrence and formation of biologically active amines in foods. Int J Food Microbio/ 1990, 11:73-84.

5. Shalaby AR: Significance of biogenic amines in food safety and human health. Food Res Int 1996, 29:675-690.

6. Bover-Cid S, Holzapfel WH: Improved screening procedure for biogenic amine production by lactic acid bacteria. Int J Food Microbiol 1999, 59:391-396.

7. Bover-Cid S, Hugas M, Izquierdo-Pulido M, Vidal-Carou MC: Amino aciddecarboxylase activity of bacteria isolated from fermented pork sausages. Int J Food Microbiol 2001, 66:185-189.

8. Lonvaud-Funel A: Biogenic amines in wines: role of lactic acid bacteria. FEMS Microbiol Lett 2001, 199:9-13.

9. Fernández M, Linares DM, Rodríguez A, Alvarez MA: Factors affecting tyramine production in Enterococcus durans IPLA 655. Appl Microbio Biotechnol 2007, 73:1400-1406.

10. Marques AP, Leitão MC, San Romão MV: Biogenic amines in wines: influence of oenological factors. Food Chem 2008, 107:853-860.

11. Lyte M: The biogenic amine tyramine modulates the adherence of Escherichia coli 0157:H7 to intestinal mucosa. J Food Prot 2004, 67:878-883. 
12. Marcobal A, De las Rivas B, Moreno-Arribas MV, Muñoz R: Identification of the ornithine decarboxylase gene in the putrescine producer Oenococcus oeni BIFI-83. FEMS Microbiol Lett 2004, 239:213-220.

13. Lucas PM, Blancato VS, Claisse O, Magni C, Lolkema JS, Lonvaud-Funel A: Agmatine deiminase pathway genes in Lactobacillus brevis are linked to the tyrosine decarboxylation operon in a putative acid resistance locus. Microbiology 2007, 153:2221-2230.

14. Landete JM, Arena ME, Pardo I, Manca de Nadra MC, Ferrer S: Comparative survey of putrescine production from agmatine deamination in different bacteria. Food Microbiol 2008, 25:882-887.

15. Greene JD, Klaenhammer TR: Factors involved in adherence of lactobacilli to human Caco-2 cells. Appl Environ Microbiol 1994, 60:4487-4494.

16. Fernández de Palencia P, Fernández M, Mohedano ML, Ladero V, Quevedo C, Alvarez MA, López P: The role of tyramine synthesis by food-borne Enterococcus durans in the adaptation to the gastrointestinal tract environment. App/ Environ Microbio/ 2011, 77:699-702.

17. Moreno-Arribas V, Torlois S, Joyeux A, Bertrand A, Lonvaud-Funel A: Isolation, properties and behaviour of tyramine-producing lactic acid bacteria from wine. J App/ Microbiol 2000, 88:584-593.

18. Lucas PM, Landete JM, Coton M, Coton E, Lonvaud-Funel A: The tyrosine decarboxylase operon of Lactobacillus brevis IOEB 9809: characterization and conservation in tyramine-producing bacteria. FEMS Microbiol Lett 2003, 229:65-71.

19. Wolken WA, Lucas PA, Lonvaud-Funel A, Lolkema JS: The mechanism of the tyrosine transporter TyrP supports a proton motive decarboxylation pathway in Lactobacillus brevis. J Bacteriol 2006, 188:2198-2206.

20. Marieb EN, Hoehn K: Human anatomy and physiology. 8 th edth edition. San Francisco: Benjamin Cummings Publishing Co; 2009.

21. Fernández de Palencia $P$, López $P$, Corbí AL, Peláez C, Requena T: Probiotic strains: survival under simulated gastrointestinal conditions, in vitro adhesion to Caco-2 cells and effect on cytokine secretion. Eur Food Res Technol 2008, 227:1475-1484.

22. Fernández de Palencia P, Werning ML, Sierra-Filardi E, Dueñas MT, Irastorza A, Corbí AL, López P: Probiotic properties of the 2-substituted (1,3)- $\beta$-Dglucan-producing bacterium Pediococcus parvulus 2.6. Appl Environ Microbiol 2009, 75:4887-4891.

23. Garai-lbabe G, Dueñas MT, Irastorza A, Sierra-Filardi E, Werning ML, López P, Corbí AL, Fernández de Palencia P: Naturally occurring 2-substituted $(1,3)$ $\beta$-D-glucan producing Lactobacillus suebicus and Pediococcus parvulus strains with potential utility in the production of functional foods. Biores Technol 2010, 101:9254-9263.

24. Moreno-Arribas $V$, Lonvaud-Funel A: Tyrosine decarboxylase activity of Lactobacillus brevis IOEB 9809 isolated from wine and Lb. brevis ATCC 367. FEMS Microbiol Lett 1999, 180:55-60.

25. Griswold AR, Jameson-Lee M, Burne RA: Regulation and physiological significance of the agmatine deiminase system of Streptococcus mutans UA159. J Bacterio/ 2006, 188:834-841.

26. Alberto MR, Arena ME, Manca de Nadra MC: Putrescine production from agmatine by Lactobacillus hilgardii: effect of phenolic compounds. Food Control 2007, 18:898-903.

27. Griswold AR, Chen YYM, Burne RA: Analysis of an agmatine deiminase gene cluster in Streptococcus mutans UA159. J Bacteriol 2004, 186:1902-1904.

28. Cotter PD, Hill C: Surviving the acid test: responses of gram-positive bacteria to low pH. Microbiol Mol Biol Rev 2003, 67:429-445.

29. Arena MP, Romano A, Capozzi V, Beneduce L, Ghariani M, Grieco F, Lucas P, Spano G: Expression of Lactobacillus brevis IOEB 9809 tyrosine decarboxylase and agmatine deiminase genes in wine correlates with substrate availability. Lett App/ Microbiol 2011, 53:395-402.

30. Tuomola EM, Salminen SJ: Adhesion of some probiotic and dairy Lactobacillus strains to Caco-2 cell cultures. Int J Food Microbiol 1998, 41:45-51.

31. Blachier F, Davila AM, Benamouzig R, Tome D: Channelling of arginine in $\mathrm{NO}$ and polyamine pathways in colonocytes and consequences. Front Biosci 2011, 16:1331-1343.

32. Mayeur C, Veuillet G, Michaud M, Raul F, Blottière HM, Blachier F: Effects of agmatine accumulation in human colon carcinoma cells on polyamine metabolism, DNA synthesis and the cell cycle. Biochim Biophys Acta 2005, 1745:111-123.
33. Van den Berg CM, Blob LF, Kemper EM, Azzaru AJ: Tyramine pharmacokinetics and reduced bioavailability with food. J Clin Pharmacol 2003, 43:604-609.

34. Horwitz D, Lovenberg W, Engelman K, Sjoerdsma A: Monoamine Oxidase inhibitors, tyramine, and cheese. J Am Med Assoc 1964, 188:1108-1110.

35. Biol-N'Garagba MC, Greco S, George P, Huqueny I, Louisot P: Polyamine participation in the maturation of glycoprotein fucosylation, but not sialylation, in rat small intestine. Pediatr Res 2002, 51:625-634.

36. Deloyer P, Peulen $O$, Dandrifosse G: Dietary polyamines and nonneoplastic growth and disease. Eur J Gastroenterol Hepatol 2001, 13:1027-1032

37. Gerner EW, Meyskens FL: Polyamines and cancer: old molecules, new understanding. Nat Rev Cancer 2004, 4:781-792.

38. De Man JC, Rogosa M, Sharpe ME: A medium for the cultivation of lactobacilli. J App/ Bacteriol 1960, 23:130-135.

39. Marteau P, Minekus M, Havenaar R, Huis In't Veld JH: Survival of lactic acid bacteria in a dynamic model of the stomach and small intestine: validation and the effects of bile. J Dairy Sci 1997, 80:1031-1037.

40. Krause I, Bockhardt A, Neckermann H, Henle T, Klostermeyer $\mathrm{H}$ : Simultaneous determination of amino acids and biogenic amines by reversed-phase high performance liquid chromatography of the dabsyl derivatives. J Chromatogr A 1995, 715:67-79.

41. Calles-Enríquez M, Eriksen BH, Andersen PS, Rattray FP, Johansen AH, Fernández M, Ladero V, Alvarez MA: Sequencing and transcriptional analysis of the Streptococcus thermophilus histamine biosynthesis gene cluster: factors that affect differential hdcA expression. Appl Environ Microbiol 2010, 76:6231-6238

42. Torriani S, Gatto V, Sembeni S, Tofalo R, Suzzi G, Belletti N, Gardini F, BoverCid S: Rapid detection and quantification of tyrosine decarboxylase gene $(t d c)$ and its expression in gram-positive bacteria associated with fermented foods using PCR-based methods. J Food Prot 2008, 71:93-101.

doi:10.1186/1471-2180-12-247

Cite this article as: Russo et al:: Biogenic amine production by the wine Lactobacillus brevis IOEB 9809 in systems that partially mimic the gastrointestinal tract stress. BMC Microbiology 2012 12:247.

\section{Submit your next manuscript to BioMed Central and take full advantage of:}

- Convenient online submission

- Thorough peer review

- No space constraints or color figure charges

- Immediate publication on acceptance

- Inclusion in PubMed, CAS, Scopus and Google Scholar

- Research which is freely available for redistribution

Submit your manuscript at www.biomedcentral.com/submit
C Biomed Central 